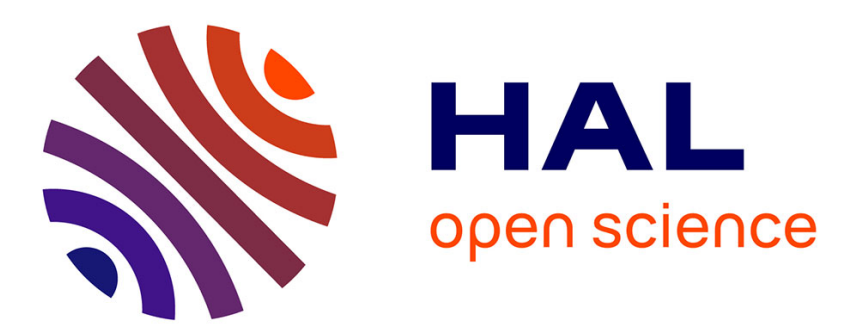

\title{
Experimental investigation of the effect of temperature on the first desorption isotherm of concrete
}

\author{
Stéphane Poyet
}

\section{To cite this version:}

Stéphane Poyet. Experimental investigation of the effect of temperature on the first desorption isotherm of concrete. Cement and Concrete Research, 2009, 39 (11), pp.1052-1059. 10.1016/j.cemconres.2009.06.019 . cea-01272821v2

\section{HAL Id: cea-01272821 \\ https://hal-cea.archives-ouvertes.fr/cea-01272821v2}

Submitted on 21 Jul 2021

HAL is a multi-disciplinary open access archive for the deposit and dissemination of scientific research documents, whether they are published or not. The documents may come from teaching and research institutions in France or abroad, or from public or private research centers.
L'archive ouverte pluridisciplinaire HAL, est destinée au dépôt et à la diffusion de documents scientifiques de niveau recherche, publiés ou non, émanant des établissements d'enseignement et de recherche français ou étrangers, des laboratoires publics ou privés. 


\title{
Experimental investigation of the effect of temperature on the first desorption isotherm of concrete
}

\author{
Stéphane Poyet \\ CEA, DEN, DPC, SCCME, Laboratoire d'Etude du Comportement des Bétons et des Argiles, F-91191 Gif-sur-Yvette Cedex, France
}

\section{A R T I C L E I N F O}

\section{Article history:}

Received 18 December 2007

Accepted 18 June 2009

\section{Keywords:}

Temperature

Surface area

Adsorption

Durability

Concrete

Radioactive waste

Waste management

\begin{abstract}
A B S T R A C T
In the framework of the radioactive waste management in France, interim storage concrete structures should be submitted to temperatures up to $80^{\circ} \mathrm{C}$ and subsequent desiccation. The impact of temperature on the sorption properties of concretes has been poorly studied and results are scarce. An experimental campaign was thus carried out to characterize the first desorption isotherms of a modern concrete at $30^{\circ} \mathrm{C}$ and $80{ }^{\circ} \mathrm{C}$. The results show a significant influence of the temperature increase that will have to be accounted for the durability assessment of the long-term interim storage concrete structures. Investigating the causes of these modifications, it appeared that desorption induced by temperature might be the principal mechanism rather than microstructure alteration and water properties evolution.
\end{abstract}

(c) 2009 Elsevier Ltd. All rights reserved.

\section{Introduction}

In the framework of radioactive waste management, the concrete structures for radioactive waste management are expected to undergo significant heating due to the waste thermal power. In the French concept of subsurface structures, the cooling is likely to be achieved using natural convection with air taken from outside. Doing so, the concrete temperature is expected to reach (but not to exceed) $80^{\circ} \mathrm{C}$ in normal conditions and the concrete structure is expected to undergo severe drying (due to the temperature increase of the ambient air) $[1,2]$. The durability assessment of these structures over 300 years thus requires the accurate knowledge of the sorption properties of concretes at such unusual temperature levels with particular interest in desorption (corresponding to the drying process).

The influence of temperature on the sorption isotherms has been poorly studied and experimental results are scarce in the scientific literature. Among these studies Daïan has experimentally determined the adsorption isotherms of a water-cured mortar at four different temperatures: $20,35,45$ and $55^{\circ} \mathrm{C}[3,4]$. The samples have been initially dried at $80^{\circ} \mathrm{C}$ and then exposed to different increasing $\mathrm{RH}$ for the four temperatures. The curves thus obtained are reproduced on Fig. 1 (according to the results published in [4]). The temperature influence can be summarised as follows: the higher the temperature, the lesser the amount of water adsorbed. Nevertheless, the offset between the curves obtained at $20^{\circ} \mathrm{C}$ and $55^{\circ} \mathrm{C}$ was found to be low.

E-mail address: stephane.poyet@cea.fr.
This observation is in good agreement with the experiments of Radjy et al. [5] who characterised the first adsorption branch of two mature (about 2 years old) steam-cured at early-age (at nearly $100{ }^{\circ} \mathrm{C}$ ) hardened cement pastes with water-to-cement ratio (W/C ratio) equal to 0.35 and 0.45 respectively for temperatures between $0{ }^{\circ} \mathrm{C}$ and $60{ }^{\circ} \mathrm{C}$. The results have shown a very limited dependence of the isotherms to temperature in this range. In the same way, the first desorption isotherm of a mature (kept 1 year under water) hardened cement paste cured at ambient temperature with a $\mathrm{W} / \mathrm{C}$ ratio equal to 0.50 was characterised for temperatures between $0{ }^{\circ} \mathrm{C}$ and $40{ }^{\circ} \mathrm{C}$. As mentioned before, the resulting desorption isotherms showed hardly any dependence on the temperature used.

In a recent attempt to develop a model capable of predicting the behaviour of concrete in any arbitrary environment Ishida et al. [6] have characterised the sorption isotherms (the first adsorption and the first desorption branches) of an 80-day water-cured hardened cement paste (W/C ratio equal to 0.50 ) for $20^{\circ} \mathrm{C}, 40{ }^{\circ} \mathrm{C}$ and $60{ }^{\circ} \mathrm{C}$. The results obtained for the first adsorption have shown little differences between the curves for the three temperatures. However, the results of the first desorption appeared to be much different: the first desorption isotherm was greatly modified by the temperature increase. The decrease of the amount of water adsorbed at higher temperatures was more pronounced than that obtained for adsorption. Moreover the shape of the isotherms was also modified by the temperature increase.

These facts have already been pointed out by Hundt and Kantelberg [7] who characterised the first desorption isotherm of different cementitious materials for temperatures ranging from $20^{\circ} \mathrm{C}$ to $70{ }^{\circ} \mathrm{C}$. 


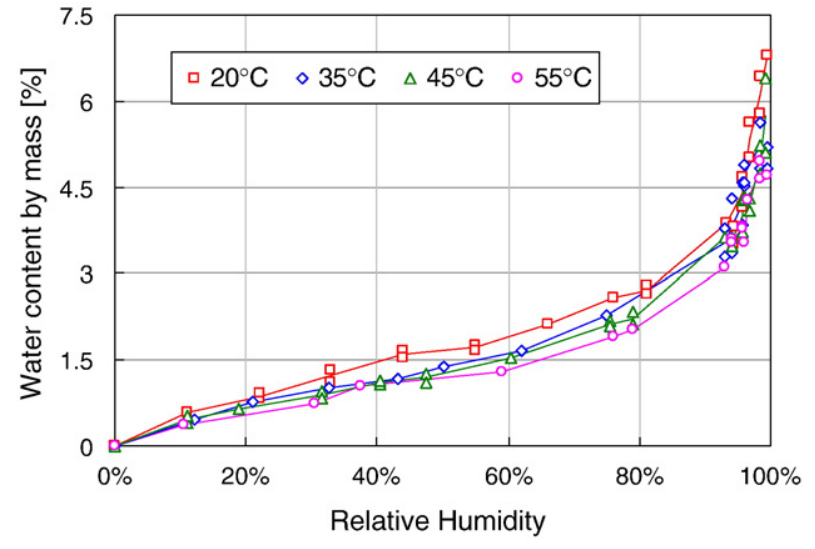

Fig. 1. Adsorption curves for a mortar between $20^{\circ} \mathrm{C}$ and $55^{\circ} \mathrm{C}$ after Daïan [4].

The results obtained with a 3.6 year old mortar (W/C ratio equal to 0.50 ) are reproduced on Fig. 2 (according to the data published in [7]). As mentioned before the higher the temperature, the lesser the amount of water adsorbed at equilibrium. One can see on Fig. 2 that the $20^{\circ} \mathrm{C}$ desorption isotherm was nearly a straight line. This pattern was greatly modified when working at higher temperatures: see for instance the linear part between $20 \%$ and $50 \%$ with a decreasing slope related to the temperature increase and the pronounced upwards deviation for high $\mathrm{RH}$. In addition, one can note the significant decrease of the amount of water adsorbed at saturation as a function of temperature: the higher the temperature, the lesser the amount of water at saturation. Hardened cement pastes with varying W/C (between 0.40 and 0.55 ) and concretes with various preliminary treatments were also tested by Hundt and Kantelberg [7], all the results obtained in this study (various cementitious materials with various curing methods) confirm all these observations.

An experimental campaign was then undertaken to highlight the influence of temperature and gather experimental data for further numerical approaches and durability assessment of interim storage concrete structures. The first desorption isotherm of a modern highperformance concrete was characterised at $30^{\circ} \mathrm{C}$ and $80^{\circ} \mathrm{C}$. The temperature dependence of cementitious materials sorption properties is generally related to the coarsening of the pore structure (ettringite dissolution and $\mathrm{C}-\mathrm{S}-\mathrm{H}$ alteration) together with the evolution of water properties [8-11]. In this study, the examination of the results obtained indicates that another phenomenon may be at work and

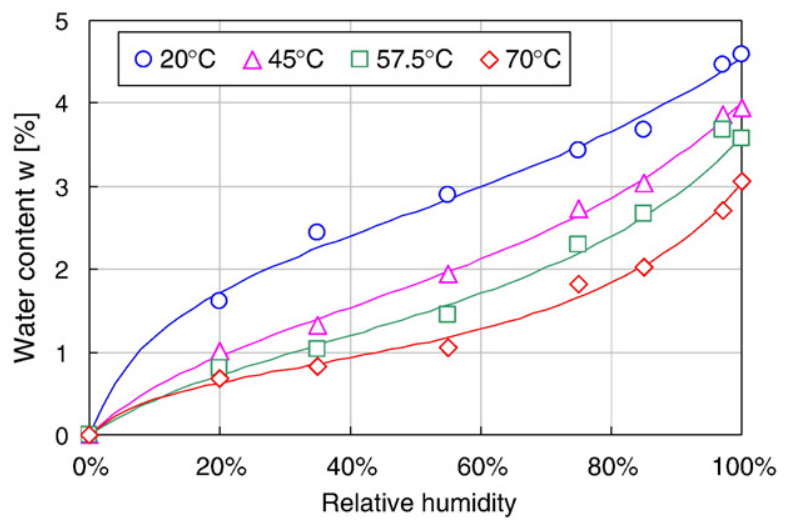

Fig. 2. First desorption isotherms for a mature mortar for four temperatures ranging from $20{ }^{\circ} \mathrm{C}$ to $70{ }^{\circ} \mathrm{C}$ according to Hundt and Kantelberg [7].
Table 1

Concrete formulation.

\begin{tabular}{lllrl}
\hline Component & Nature & Origin & Qty & Unit \\
\hline Cement & CEM I 52.5 & Lafarge Val d'Azergues, France & 400 & $\mathrm{~kg} / \mathrm{m}^{3}$ \\
Sand & Calcareous [0-5] & Boulonnais quarry, France & 858 & $\mathrm{~kg} / \mathrm{m}^{3}$ \\
Gravel & Calcareous [5-12.5] & Boulonnais quarry, France & 945 & $\mathrm{~kg} / \mathrm{m}^{3}$ \\
Water & - & - & 172 & $\mathrm{~L} / \mathrm{m}^{3}$ \\
Superplasticizer & Glenium 27 & BASF & 10 & $\mathrm{~kg} / \mathrm{m}^{3}$ \\
\hline
\end{tabular}

suggests that the microstructure alteration and the water properties evolution may have negligible effects.

\section{Experimental programme}

\subsection{Material tested}

The material used for the experiments was a modern high-performance concrete, the formulation is reported on Table 1. It is based on CEM I cement. The water-to-cement ratio (by weight) is equal to 0.43 . This formulation was used because it is one of those which are studied in the framework of radioactive waste management by the French agency for radioactive waste management (Andra).

The main properties of the concrete have been determined experimentally on samples taken out of the same batch and cured more than 1 year under water at $20^{\circ} \mathrm{C}$. The values obtained are reported on Table 2. All the characterization tests were performed on saturated samples at $20^{\circ} \mathrm{C}$ (except for the gas permeability measurements and water porosity which implied complete drying at $60^{\circ} \mathrm{C}$ ) and after thermal treatment at $80^{\circ} \mathrm{C}$ ( until constant mass was achieved, residual properties after cooling). The intrinsic permeability to gas (nitrogen) was estimated using the Klinkenberg approach [12].

The porosity to water at $30^{\circ} \mathrm{C}$ and $80^{\circ} \mathrm{C}$ was estimated using the mass loss obtained using silica gel ( $\mathrm{RH} 3 \%)$. It was also estimated using two other usual experimental protocols: drying at $60{ }^{\circ} \mathrm{C}$ with silica gel and drying at $105^{\circ} \mathrm{C}$. All the results are presented in Table 3 . The concrete saturated density was calculated using hydrostatic weighing, the mean value was found to be equal to 2.48 .

\subsection{Technique used}

The concrete first desorption isotherm was determined at $30^{\circ} \mathrm{C}$ and $80{ }^{\circ} \mathrm{C}$. The desiccator method using saturated salt solutions was chosen for its simplicity and its reliability. This is a standalone system which minimises human interventions and is recommended by the European Committee for Standardization [13]. The different RHs
Table 2

Main concrete properties, all given data are at least the mean of three values.

\begin{tabular}{llll}
\hline Concrete properties & $20{ }^{\circ} \mathrm{C}$ & $80{ }^{\circ} \mathrm{C}$ & Unit \\
\hline Tensile splitting strength (Brazilian test) & 5.80 & 4.95 & $\mathrm{MPa}$ \\
Compressive strength & 89.7 & 79.5 & $\mathrm{MPa}$ \\
Elastic modulus & 49.2 & 41.7 & $\mathrm{GPa}$ \\
Poisson's ratio & 0.18 & 0.17 & - \\
Water porosity & 11.3 & 12.0 & $\%$ \\
Intrinsic permeability (nitrogen) & $2.0 \times 10^{-17}$ & $4.2 \times 10^{-17}$ & $\mathrm{~m}^{2}$ \\
Klinkenberg coefficient & 0.13 & 0.06 & $\mathrm{MPa}$ \\
Heat conductivity & 2.49 & 2.09 & $\mathrm{~W} / \mathrm{mK}$ \\
\hline
\end{tabular}

Table 3

Porosity to water according to the experimental protocol.

\begin{tabular}{lllll}
\hline Protocol & $\begin{array}{l}30{ }^{\circ} \mathrm{C} \\
(\text { silica gel) }\end{array}$ & $\begin{array}{l}60{ }^{\circ} \mathrm{C} \\
(\text { silica gel) }\end{array}$ & $\begin{array}{l}80{ }^{\circ} \mathrm{C} \\
(\text { silica gel) }\end{array}$ & $\begin{array}{l}105{ }^{\circ} \mathrm{C} \\
\text { (no silica gel) }\end{array}$ \\
\hline Porosity to water & $10.7 \%$ & $11.3 \%$ & $12.0 \%$ & $12.3 \%$ \\
\hline
\end{tabular}


which were used are given in Table 4 . For $\mathrm{RH}=100 \%$ deionised water was used (without any salt) and for $\mathrm{RH}=3 \%$ silica gel was used (without water). The saturated salt solutions were prepared according to international recommendations $[13,14]$ and the resulting $\mathrm{RHs}$ were verified before use.

\subsection{Sample preparation}

Characterization of the sorption isotherm using the gravimetric method requires long-term experiments due to the sample dimensions and water transfer properties of the materials tested. In order to reduce the experiment duration the samples used usually have small dimensions: thin slices [15-17], powders [18-20], crushed or sawn small specimens (up to $1 \mathrm{~cm}$ max) [4,6,20-22]. One can note that such sample shape and dimensions greatly differ from a concrete Representative Volume Element (RVE). In addition, if the sample preparation has an effect on the experiments (for instance superficial microcracking or carbonation) then this effect may concern a great part of the sample volume because of its thinness.

In this study an attempt was made to use massive samples as close as possible to a RVE. Hence "massive" cylindrical specimens with diameter and height equal to $40 \mathrm{~mm}$ were used. One could note that this dimension is far from the minimum $100 \mathrm{~mm}$ recommended in the European standard EN 12390-1 [23], nevertheless this value appeared as the best compromise between the duration of the experiments and the representativeness of the samples (the weight of the resulting samples was about $120 \mathrm{~g}$ ).

The samples were cored from $11 \mathrm{~cm} \times 22 \mathrm{~cm}$ specimens cured under water (with added lime) at $20^{\circ} \mathrm{C}$ at least 1 year after casting. All the samples were taken from the same batch (the one used for the characterisation whose results are presented in Table 2). No preventative measure was taken to prevent carbonation since it is expected to affect only a small zone at the surface of the samples that is to say a negligible volume when compared to the total volume of the samples.

\subsection{Dry and saturated states}

The reference dry state is essential for the correct evaluation of the sorption curves. It is generally estimated using oven-drying. This treatment is known to be too aggressive for cement-based materials (microcracking and modification of pore network) and alternate techniques do exist (isothermal drying using hydrophilic compounds, solvent exchange, D- or P-drying...) [24-29]. Yet as far as only desorption is concerned (no preliminary drying and no further resaturation) oven-drying at $105^{\circ} \mathrm{C}$ was chosen as the reference dry state.

Table 4

RH investigated and corresponding saturated salt solutions.

\begin{tabular}{|c|c|c|c|}
\hline \multirow[t]{2}{*}{ Salt used } & \multirow[t]{2}{*}{ Formula } & \multicolumn{2}{|c|}{ RH obtained at } \\
\hline & & $30^{\circ} \mathrm{C}$ & $80^{\circ} \mathrm{C}$ \\
\hline Deionised water & $\mathrm{H}_{2} \mathrm{O}$ & $100 \%$ & $100 \%$ \\
\hline Potassium sulphate & $\mathrm{K}_{2} \mathrm{SO}_{4}$ & $96 \%$ & $95 \%$ \\
\hline Sodium sulphate & $\mathrm{Na}_{2} \mathrm{SO}_{4} 10 \mathrm{H}_{2} \mathrm{O}$ & - & $90 \%$ \\
\hline Potassium nitrate & $\mathrm{KNO}_{3}$ & $90 \%$ & - \\
\hline Potassium chloride & $\mathrm{KCl}$ & $85 \%$ & - \\
\hline Sodium chloride & $\mathrm{NaCl}$ & $75 \%$ & $74 \%$ \\
\hline Sodium nitrate & $\mathrm{NaNO}_{3}$ & - & $65 \%$ \\
\hline Ammonium nitrate & $\mathrm{NH}_{4} \mathrm{NO}_{3}$ & $63 \%$ & - \\
\hline Sodium bromide & $\mathrm{NaBr}$ & $55 \%$ & $51 \%$ \\
\hline Potassium carbonate & $\mathrm{K}_{2} \mathrm{CO}_{3}$ & - & $42 \%$ \\
\hline Magnesium chloride & $\mathrm{MgCl}_{2} 6 \mathrm{H}_{2} \mathrm{O}$ & $33 \%$ & $26 \%$ \\
\hline Lithium chloride & $\mathrm{LiCl}$ & $12 \%$ & $10 \%$ \\
\hline Silica gel & $\mathrm{SiO}_{2}$ & $3 \%$ & $3 \%$ \\
\hline
\end{tabular}

The initial saturated state was achieved using the one-year cure under water (with lime to prevent carbonation). No other specific procedure was used (for instance resaturation using vacuum).

\subsection{Experimental protocol}

The best method for the characterisation of the first desorption isotherm consists in submitting a unique set of initially saturated samples to decreasing RH steps and waiting for equilibrium for each step $[5,7,20,30,31]$. This method was inappropriate for this study given that the time needed to reach equilibrium was expected to be too long due to the massive samples used. It was then decided to use different set of samples to be submitted to a unique RH. The number of sample set for each temperature $\left(30^{\circ} \mathrm{C}\right.$ and $80^{\circ} \mathrm{C}$ ) was equal to the number of salt solutions ( 10 sets for each temperature including deionised water and silica gel, see Table 4). This method allowed the simultaneous determination of each point of the curve and a corresponding estimated reduction of the experiments time by a factor of 10 . It was however expected to induce some variability since different specimens were to be used.

The $40 \mathrm{~mm} \times 40 \mathrm{~mm}$ cylinder samples were weighed in air and under water before the beginning of the experiments and their volume and saturated density were computed (weighing was carried out using a $1 \mathrm{mg}$ accurate device). They were then put in hermetic containers by groups of three above the saturated salt solutions and the containers were kept in two different ovens regulating the temperature to $30^{\circ} \mathrm{C}$ and $80^{\circ} \mathrm{C}$. A view of the $40 \mathrm{~mm} \times 40 \mathrm{~mm}$ samples and of the hermetic containers is presented in Fig. 3. The containers were opened periodically to measure the mass of the samples. The latter were left as long as possible in the containers in order to get as close as possible to equilibrium.

\section{Experimental results}

\subsection{Mass variation and water transfer properties}

On the basis of the periodic mass measurements, the mean relative mass variation $(\Delta m / m)$ of the samples for each temperature and $\mathrm{RH}$ could be computed following the classical relation:

$\left(\frac{\Delta m}{m}\right)(t)=\frac{m(t)-m_{0}}{m_{0}}$

where $m_{0}$ and $m(t)$ are the initial sample mass (saturated) and the mass for the time $t$. The results are presented in Figs. 4 and 5 for $30^{\circ} \mathrm{C}$ and $80{ }^{\circ} \mathrm{C}$ respectively.

The desorption experiments spanned over 1200 days and 500 days for $30{ }^{\circ} \mathrm{C}$ and $80^{\circ} \mathrm{C}$ respectively. Such experiment durations (qualitatively) appear to be sufficient to reach equilibrium at $80{ }^{\circ} \mathrm{C}$ but not at $30{ }^{\circ} \mathrm{C}$ for which the samples kept between $55 \%$ and $85 \%$ still present mass variation after 1200 days. Nevertheless, the amount of water in excess (with respect to the equilibrium to be reached) is expected to be low and the corresponding error negligible. One can note that for each temperature the patterns are similar: the mass loss kinetics is maximal in the early days, it is then continuously reduced as far as the drying proceeds and the equilibrium is approached. In addition, the lower the RH the higher is the mass loss. The main differences between the results for both temperatures lie in the mass loss kinetics and in the value reached at equilibrium (the last point will be discussed in the next chapter).

When examining Figs. 4 and 5 it is obvious that the time needed to reach the equilibrium at $80^{\circ} \mathrm{C}$ is much lower than the one needed at $30{ }^{\circ} \mathrm{C}$. For instance, the time needed to reach $90 \%$ of the mass loss is about one month at $80{ }^{\circ} \mathrm{C}$; it is extended to more than 1 year at $30^{\circ} \mathrm{C}$. This point has already been studied by several authors who showed the drying acceleration and the increase of the water transfer properties with temperature [32-36]. 


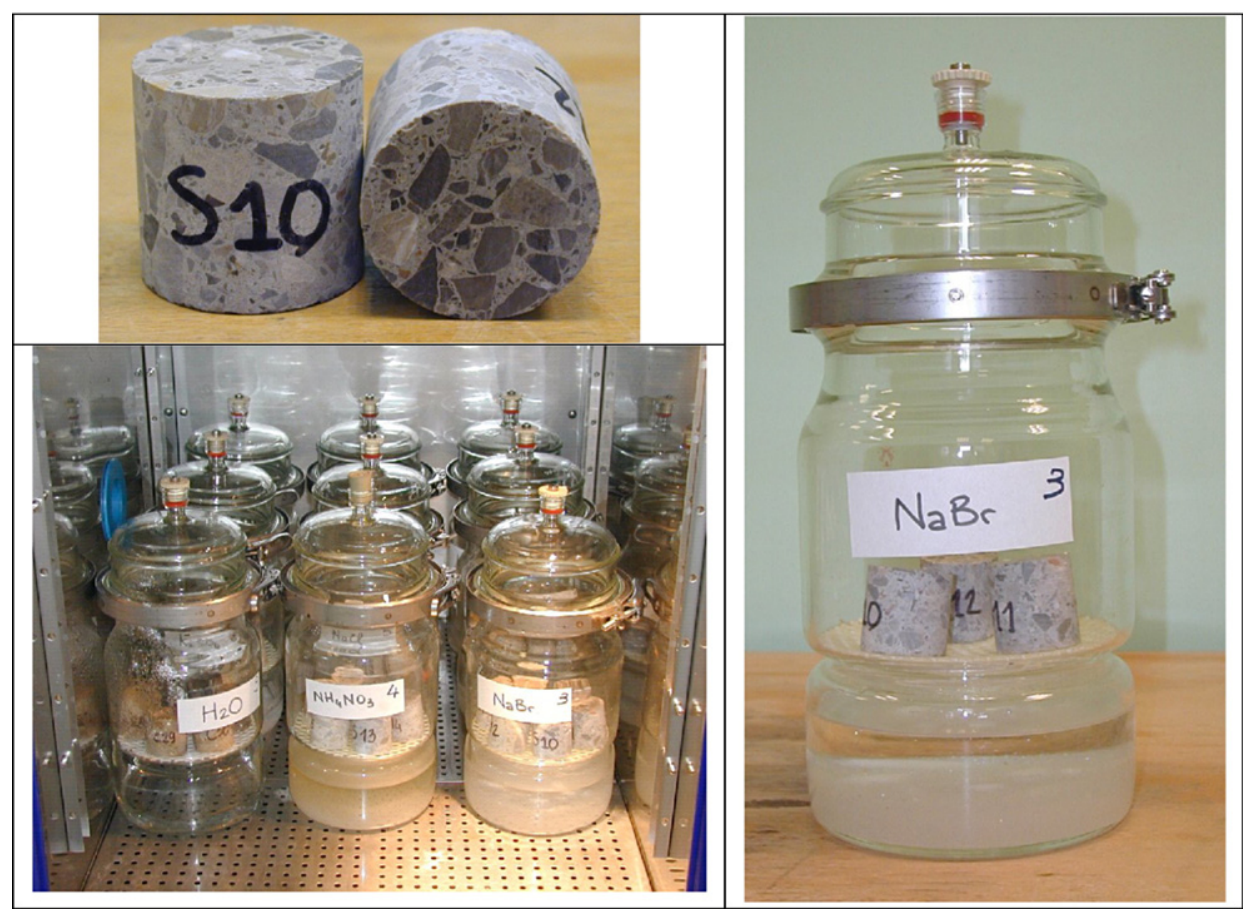

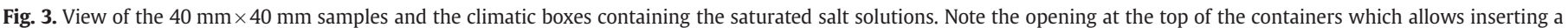
probe for verification of both temperature and $\mathrm{RH}$.

\subsection{First desorption isotherms}

In order to determine the first desorption isotherms at $30^{\circ} \mathrm{C}$ and $80^{\circ} \mathrm{C}$, the amount of water retained according to the $\mathrm{RH}$ was expressed using the mass water content $w$ :

$w(T, R H)=\frac{m_{\mathrm{w}}(T, R H)}{m_{\mathrm{s}}}$,

where $m_{\mathrm{w}}$ and $m_{\mathrm{s}}$ are the mass of adsorbed water and the mass of the dry material respectively. It was computed using the experimental mass variations $(\Delta m / m)$ :

$w(T, R H)=\frac{d_{\text {sat }}}{d_{\text {sat }}-\phi}\left[\left(\frac{\Delta m}{m}\right)(T, R H)+\frac{\phi}{d_{\text {sat }}}\right]$,

where $d_{\text {sat }}$ and $\phi$ are the saturated initial density and the porosity respectively. The results are presented in Fig. 6, the reference dry state

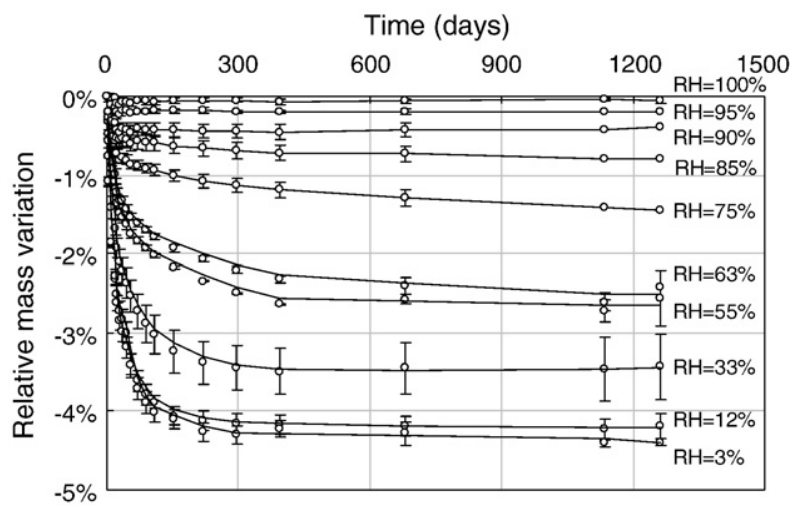

Fig. 4. Mass variation of the samples kept at $30^{\circ} \mathrm{C}$ (each value is the average value obtained using three samples, the error bar stands for the standard deviation). was fixed using oven-drying at $105^{\circ} \mathrm{C}$; that is to say the value of the porosity $\phi$ needed in Eq. ( 3 ) is equal to $12.3 \%$.

The symbols stand for the experimental results derived from the experiments whereas the solid lines stand for a curve-fitting using the GAB model [37-39]. The GAB model is a three-parameter evolved version of the BET model (with a supplementary parameter $k$ ), it can be written as follows:

$w(h)=\frac{C k w_{\mathrm{m}} h}{(1-k h)[1+(C-1) k h]}$,

where $C, k$ and $w_{\mathrm{m}}$ are the three parameters of the GAB model and $h$ is the relative humidity. The GAB model is used here because it is based on physical phenomena (which yield a correct isotherm shape), it was shown that it can be used almost over the whole $\mathrm{RH}$ range and offers the best fit among various adsorption models [37,40-43]. Moreover this model is widely used in various fields and it has already proven its suitability for cementitious materials

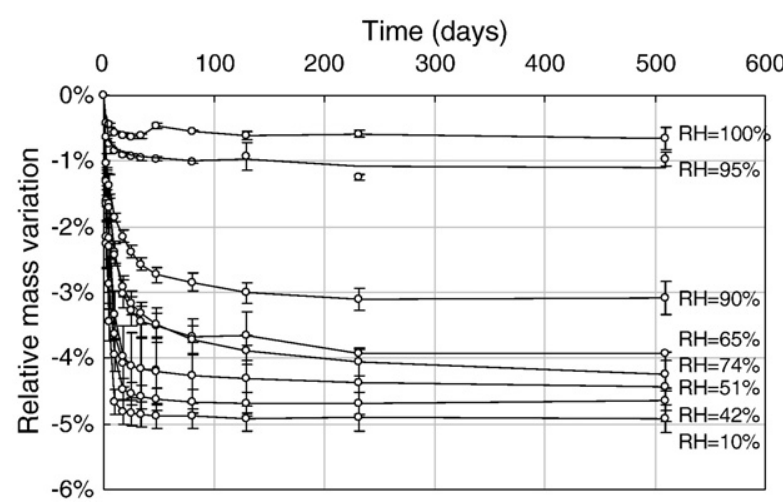

Fig. 5. Mass variation of the samples kept at $80{ }^{\circ} \mathrm{C}$ (each value is the average value obtained using three samples, the error bar stands for the standard deviation). 


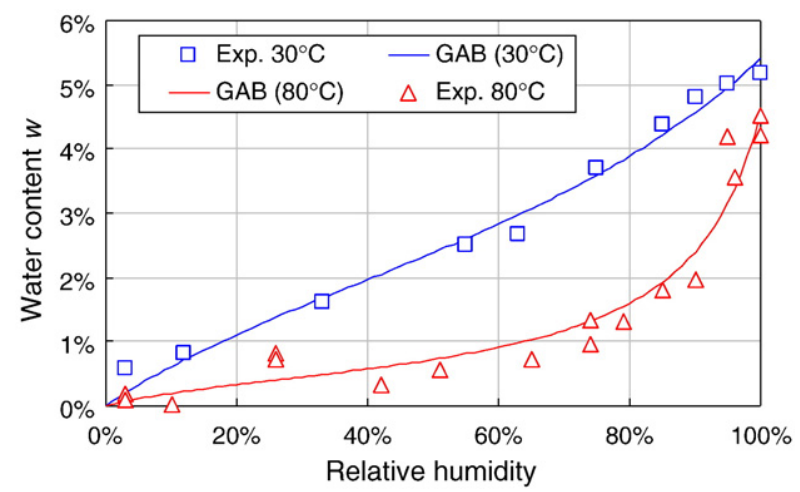

Fig. 6. First desorption isotherms at $30^{\circ} \mathrm{C}$ and $80{ }^{\circ} \mathrm{C}$.

[44-46]. The values of the three parameters of the GAB model are reported in Table 5.

Looking at Fig. 6, one can easily notice that temperature has a tremendous impact on the first desorption isotherm: at $30{ }^{\circ} \mathrm{C}$ the curve can almost be described by a straight line from the origin up to the saturation point $(w \approx 5.4 \%)$ whereas at $80^{\circ} \mathrm{C}$ high non-linearity appears. In addition to the alteration of the curve morphology, one can note that for a given $\mathrm{RH}$ the water content at equilibrium is always reduced at $80^{\circ} \mathrm{C}$ (when compared to the values obtained at $30^{\circ} \mathrm{C}$ ). This effect even appears for $\mathrm{RH}=100 \%$ : an initially saturated sample whose temperature is suddenly increased up to $80{ }^{\circ} \mathrm{C}$ undergoes a significant mass loss: from $5.4 \%$ to $4.6 \%$. The reduction of the water content at equilibrium is not constant over the whole $\mathrm{RH}$ range; for instance for $\mathrm{RH}=100 \%$ the difference in the water content is about $0.8 \%$ (absolute value) whereas it is about $2.3 \%$ for $\mathrm{RH}=80 \%$. This effect can be, for instance, quantified using the water content ratio (by mass) $r_{\mathrm{w}}$ :

$r_{\mathrm{w}}(R H, T)=\frac{w(T, R H)}{w\left(30^{\circ} \mathrm{C}, R H\right)}$.

Fig. 7 presents the evolution of the water content (by mass) $r_{\mathrm{w}}$ as a function of $\mathrm{RH}$ for the experiments presented in this study. Data derived from the work of Hundt and Kantelberg [7] are also presented; in this case the two temperatures were $20^{\circ} \mathrm{C}$ and $70{ }^{\circ} \mathrm{C}$, and different cementitious materials were used (hardened cement pastes with different $\mathrm{W} / \mathrm{C}$, mortar and concrete with different cures or preconditioning methods). Despite these differences, one can note that the results obtained in this study are in good agreement with the results of Hundt and Kantelberg. The water content ratio appears not to be constant over the full $\mathrm{RH}$ range: the general shape of the curve is parabolic and thus presents a minimum value of about 0.3 which is roughly located at $\mathrm{RH}=35 \%$. The maximal value of the ratio $r_{\mathrm{w}}=0.85$ is reached at saturation (for $\mathrm{RH}=100 \%$ ). This fact is very important, because it means that the saturation state is not constant versus temperature. It implies that a saturated concrete becomes oversaturated when the temperature increases. As a consequence the concrete is out of equilibrium and water is released and evacuated into the environment: this phenomenon can clearly be seen on Fig. 5 on which the mass loss of saturated samples kept at $\mathrm{RH}=100 \%$ and $80{ }^{\circ} \mathrm{C}$ can be seen whereas saturated samples kept at $30{ }^{\circ} \mathrm{C}$ and $\mathrm{RH}=100 \%$ do not exhibit such behaviour (Fig. 4).

Table 5

Data for the fitting of the GAB model at $30{ }^{\circ} \mathrm{C}$ and $80^{\circ} \mathrm{C}$

\begin{tabular}{llll}
\hline Temperature & $C[-]$ & $k[-]$ & $w_{\mathrm{m}}[\mathrm{kg} / \mathrm{kg}]$ \\
\hline $30{ }^{\circ} \mathrm{C}$ & 4.690 & 0.592 & $2.534 \%$ \\
$80^{\circ} \mathrm{C}$ & 6.010 & 0.897 & $0.480 \%$ \\
\hline
\end{tabular}

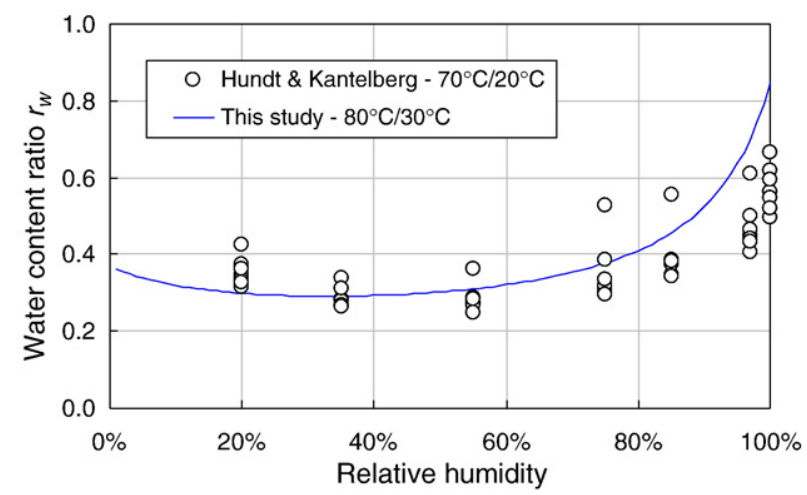

Fig. 7. Evolution of the water content ratio $r_{\mathrm{w}}$ as a function of $\mathrm{RH}$.

\subsection{Pore structure investigation}

In order to quantify the influence of temperature on the first desorption isotherm, the specific surface area $S_{\mathrm{BET}}$ was estimated using the BET model [47]:

$w=\frac{C w_{\mathrm{m}} h}{(1-h)[1+(C-1) h]}$,

where $C$ and $w_{\mathrm{m}}$ are two positive parameters of the BET model. $w_{\mathrm{m}}$ is the mass of water (for $1 \mathrm{~g}$ of dried material) needed to complete a monomolecular adsorbed layer, its value is used to compute the specific surface area $S_{\text {BET. }}$. According to the recommendations of the IUPAC [48] the BET parameters were not estimated using the experimental data from the full $\mathrm{RH}$ range. However, due to the lack of experimental data in the low RH (typically between $5 \%$ and $30 \%$ ) the fitting interval was extended up to $\mathrm{RH}=50 \%$. In so doing, it was accepted that this would not yield an accurate value of the specific surface, rather only a rough estimate. The fitted parameters are reported in Table 6 .

The specific surface area $S_{\mathrm{BET}}$ was estimated using [49]:

$S_{\mathrm{BET}}(T)=w_{\mathrm{m}}(T) \frac{A_{\mathrm{w}}}{\rho_{\mathrm{w}} V_{\mathrm{w}}}(T) N_{A}$,

where $V_{\mathrm{w}}$ and $N_{A}$ are the molar volume of water $\left(0.1808 \times 10^{-4} \mathrm{~m}^{3} /\right.$ mol and $0.1853 \times 10^{-4} \mathrm{~m}^{3} / \mathrm{mol}$ at $30{ }^{\circ} \mathrm{C}$ and $80{ }^{\circ} \mathrm{C}$ respectively) and Avogadro's number $\left(N_{A}=6.02 \cdot 10^{23}\right)$ and $A_{\mathrm{w}}$ is the area occupied by a single water molecule on the surface of the sample. The latter was estimated using the equation [50,51]:

$A_{\mathrm{w}}(T)=1.091\left[\frac{M_{\mathrm{w}}}{N_{A} \rho_{\mathrm{w}}(T)}\right]^{\frac{2}{3}}$,

where $M_{\mathrm{w}}$ is the molar mass of water $\left(18 \cdot 10^{-3} \mathrm{~kg} / \mathrm{mol}\right)$. The resulting coverage areas for one molecule of water $A_{\mathrm{w}}$ are $10.538 \mathrm{~A}^{2}$ and $10.712 \AA^{2}$ at $30{ }^{\circ} \mathrm{C}$ and $80^{\circ} \mathrm{C}$ respectively. These values are very close to $10.508 \AA^{2}$ used by Baroghel-Bouny (for $23^{\circ} \mathrm{C}$ ). Many different values were used to calculate $S_{\mathrm{BET}}$ in the literature (ranging from $10.5 \AA^{2}$ to $12.5 \AA^{2}$ ) leading to discrepancies in the specific surface area estimations and major difficulties of comparison between all the published results [46,52]. All the data used for the estimation ( $V_{\mathrm{m}}$ and $A_{\mathrm{w}}$ in particular) are however reported here which allows to estimate $S_{\mathrm{BET}}$ using different data.

Table 6

Data for the fitting of the BET model.

\begin{tabular}{lcc}
\hline Temperature & $30{ }^{\circ} \mathrm{C}$ & $80{ }^{\circ} \mathrm{C}$ \\
\hline $\mathrm{C}[-]$ & 20.8 & 22.0 \\
$W_{\mathrm{m}}[\mathrm{kg} / \mathrm{kg}]$ & $1.16 \%$ & $0.35 \%$ \\
$S_{\text {BET }}\left[\mathrm{m}^{2} / \mathrm{g}\right]$ & 41 & 13 \\
\hline
\end{tabular}




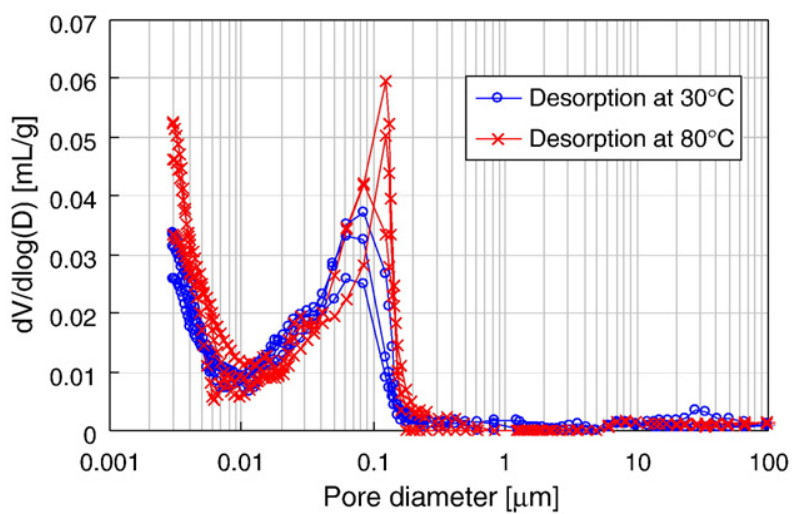

Fig. 8. Pore size distributions obtained by MIP after desorption at $30^{\circ} \mathrm{C}$ and $80^{\circ} \mathrm{C}$.

The specific surface area is obtained at $30{ }^{\circ} \mathrm{C}$ : the result is $S_{\mathrm{BET}}$ $\left(30^{\circ} \mathrm{C}\right)=41 \mathrm{~m}^{2} / \mathrm{g}$. This value is consistent with the data published (using water vapour): roughly ranging from 20 to $200 \mathrm{~m}^{2} / \mathrm{g}$ according to the cementitious material tested and the technique used $[15,22,29,52-57]$. The value of the specific surface area $S_{\mathrm{BET}}$ is divided by 3 when measured at $80{ }^{\circ} \mathrm{C}$ and falls down to $S_{\mathrm{BET}}\left(80^{\circ} \mathrm{C}\right)=13 \mathrm{~m}^{2} / \mathrm{g}$ (Table 6). These data are comparable to the results obtained by Bray and Sellevold [58] and Radjy and Richards [19] who showed that a temperature increase between ambient temperature and $90{ }^{\circ} \mathrm{C}$ or $100{ }^{\circ} \mathrm{C}$ resulted in a decrease of the BET monolayer parameter $V_{\mathrm{m}}$ estimated using water desorption experiments (and thus the specific surface area $S_{\mathrm{BET}}$ ).

In the same time, Mercury intrusion porosimetry (MIP) experiments were performed to highlight the influence of the desorption temperature on pore size distribution. The samples used for the desorption experiments at $30^{\circ} \mathrm{C}$ and $80{ }^{\circ} \mathrm{C}$ and kept at $\mathrm{RH}=3 \%$ were used. They were crushed into small parts (several millimetres), frozen by immersion into liquid nitrogen, let to dry under vacuum for seven days and then tested at ambient temperature. The results are presented on Fig. 8. One can see that for the two desorption temperatures a bi-modal pore size distribution is obtained corresponding to $\mathrm{C}-\mathrm{S}-\mathrm{H}$ nanoporosity (around $3 \mathrm{~nm}$ ) and capillary porosity (around $100 \mathrm{~nm}$ ). For desorption at $30{ }^{\circ} \mathrm{C}$, the access diameter for capillary porosity is about $70 \mathrm{~nm}$. Desorption at $80^{\circ} \mathrm{C}$ appears to slightly shift it towards larger diameters $(110 \mathrm{~nm})$ as it was already shown [25,59]. The variability observed in the intruded volume was not thought to be significant and assumed to be related to the presence of sand and aggregates in the samples together with hardened cement paste.

The specific surface areas estimated using MIP were quite different from the ones derived from desorption. A value of about $10 \mathrm{~m}^{2} / \mathrm{g}$ after desorption at $30{ }^{\circ} \mathrm{C}$ was obtained; the same value $\left(12 \mathrm{~m}^{2} / \mathrm{g}\right)$ was obtained for desorption at $80^{\circ} \mathrm{C}$ in contradiction with desorption results.

\section{Discussion}

The (slight) increase of the capillary porosity average access diameter between $30^{\circ} \mathrm{C}$ and $80^{\circ} \mathrm{C}$ observed using MIP as well as the decrease of the specific surface area is consistent with the desorption isotherm modification: the coarser the pore size, the greater the upward deviation (see for instance [22] for compacted cement pastes; $[56,60]$ for hardened cement pastes with variable water-to-cement ratio and [61-65] for compacted powders.) Yet one must note that the porosity increase (between $30^{\circ} \mathrm{C}$ and $80^{\circ} \mathrm{C}$, Table 3 ) is not compatible with the fall of the water content at saturation (it is expected to induce a water uptake at saturation leading to mass gain). The latter may be explained by the decrease of water density when temperature is increased.

However these two phenomena are believed by the author to have a small impact on the isotherms: the decrease of water density (at least between $20^{\circ} \mathrm{C}$ and $80^{\circ} \mathrm{C}$ ) as well as the coarsening of the pore structure as observed using MIP remains very limited. In the author's mind, these two phenomena cannot explain the important modifications of the desorption isotherm observed between $30^{\circ} \mathrm{C}$ and $80^{\circ} \mathrm{C}$. Moreover the difference of specific surface areas obtained using the $80^{\circ} \mathrm{C}$ isotherm and MIP led the author think that another phenomenon directly linked to temperature might be at work.

Such a phenomenon can be described as follows: adsorption is an exothermic process $[66,67]$ and according to the principle of Le Chatelier and the rule of Van't Hoff: the effect of a change in temperature on a system at equilibrium is to shift the equilibrium in the direction that acts to counteract and nullify the temperature change. This means increasing temperature hinders adsorption and promotes desorption; as a consequence a lesser number of molecules can be adsorbed. This phenomenon is very well-known in adsorption science. Many studies can be found in the literature which show the impact of temperature on sorption isotherms for different adsorbents and adsorbates [50,68-73], the results always show the same modifications of the sorption isotherms as described in this paper. Furthermore in adsorption technology, the temperature increase and the heat transfers induced by the heat of adsorption are accounted for the design of the adsorbent beds (to avoid the performance reduction due to temperature increase) and thermal treatments at elevated temperature are usually used as a method to regenerate adsorbents (this method is also known as "temperature swing adsorption") [73,74].

This effect can be described using the Clausius-Clapeyron equation which permits the evaluation of the heat involved in a change of phase for a system in equilibrium, in the case of adsorption it can be written under the form [66]:

$Q_{\mathrm{st}}(w)=-R\left[\frac{\partial \ln \left(p_{\mathrm{v}}\right)}{\partial\left({ }^{1} / \mathrm{T}\right)}\right]_{\mathrm{w}}$,

where $Q_{s t}$ is the isosteric heat of adsorption [J/mol], $T$ and $R$ are the absolute temperature $[K]$ and the universal gas constant $(R=8.3145 \mathrm{~J} /$ $\mathrm{mol} / \mathrm{K}$ ) and $p_{\mathrm{v}}$ is the water vapour pressure [Pa] at equilibrium with the adsorbed quantity $w$ respectively. In our case the heat of adsorption could be estimated using the two isotherms obtained at $30^{\circ} \mathrm{C}$ and $80^{\circ} \mathrm{C}$ using the integrated form of Eq. (9):

$Q_{\mathrm{st}}(w)=-R \frac{T_{1} T_{2}}{T_{1}-T_{2}} \ln \left[\frac{p_{\mathrm{v}}\left(T_{1}, w\right)}{p_{\mathrm{v}}\left(T_{2}, w\right)}\right]$

where $p_{\mathrm{v} 1}(w)$ and $p_{\mathrm{v} 2}(w)$ are the vapour pressures at equilibrium with the water content $w$ for the temperatures $T_{1}$ and $T_{2}$ respectively. In so

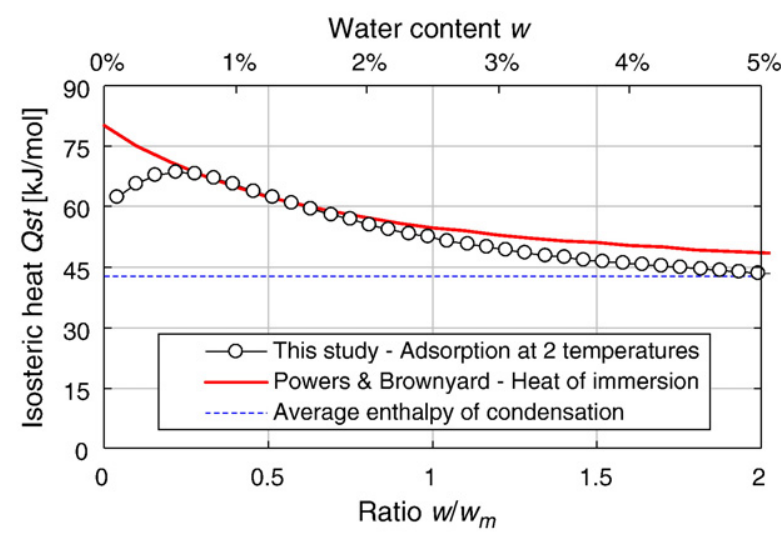

Fig. 9. Comparison between the isosteric heat of desorption obtained in this study (two isotherms at two different temperatures and Clausius-Clapeyron) and the one proposed by Powers and Brownyard using heat-of-solution tests (at ambient temperature). 
doing, it was implicitly assumed that the pore size distribution and the water properties remain constant over the whole temperature range. Fig. 9 presents the resulting evolution of the isosteric heat of desorption as a function of water content. One can see that the isosteric heat of desorption is a decreasing function of water content: the high value observed for low water contents is representative of a strong bonding between the adsorbed water molecules and the cementitious substrate whereas the decrease can be related to the drop of the influence of the substrate with the increase of the distance between adsorbed water molecules and substrate. The value reached at high water contents is equal to the average enthalpy of condensation ( $42.7 \mathrm{~kJ} / \mathrm{mol}$ between 30 and $80^{\circ} \mathrm{C}$ ): it can be considered that there is no more influence of the substrate and water molecules are bound the ones to the others (condensation).

For verification purposes, the isosteric heat of desorption obtained in this study was compared to the one proposed by Powers and Brownyard [60]. They used the heat-of-solution method on two hardened cement pastes. The method consists in dissolving paste samples in a calorimeter and measuring the heat evolved. Repeated measurements on samples containing different amounts of adsorbed water allowed them to evaluate the isosteric heat of adsorption which can be written under the following form (in $\mathrm{kJ} / \mathrm{mol}$ ):

$Q_{\mathrm{st}}(w)=L+\frac{64.6}{\left(1.31+w / w_{\mathrm{m}}\right)^{2}}$

where $L=42.7 \mathrm{~kJ} / \mathrm{mol}$ is the average condensation enthalpy of water within the range $30-80^{\circ} \mathrm{C}$. The comparison is presented on Fig. 9. One can see that except for low values of $w / w_{\mathrm{m}}$ (below 0.2 ), there is a good agreement between the two curves. This fact is important since Powers and Brownyard performed their experiments at constant (ambient) temperature. This seems to indicate that the two phenomena initially identified to explain the influence of temperature (coarsening of the pore structure and water properties evolution) might be negligible in front of the desorption induced by temperature.

Using Clausius-Clapeyron and the corresponding isosteric heat of desorption, it is possible to estimate the water content ratio $r_{\mathrm{w}}(R H, T)$ (as defined in Eq. (5)) for any arbitrary temperature. Fig. 10 presents the results obtained for temperatures ranging from $35^{\circ} \mathrm{C}$ to $80^{\circ} \mathrm{C}$. One can see that the fall of water content increases with temperature and whatever the temperature, the first desorption isotherm is expected to be modified: there is no threshold temperature. Moreover, the change depends on the temperature level: for a small temperature increase only the low-RH part of the isotherm is expected to be influenced whereas the isotherm is expected to be modified over the whole $\mathrm{RH}$ range for higher temperatures.

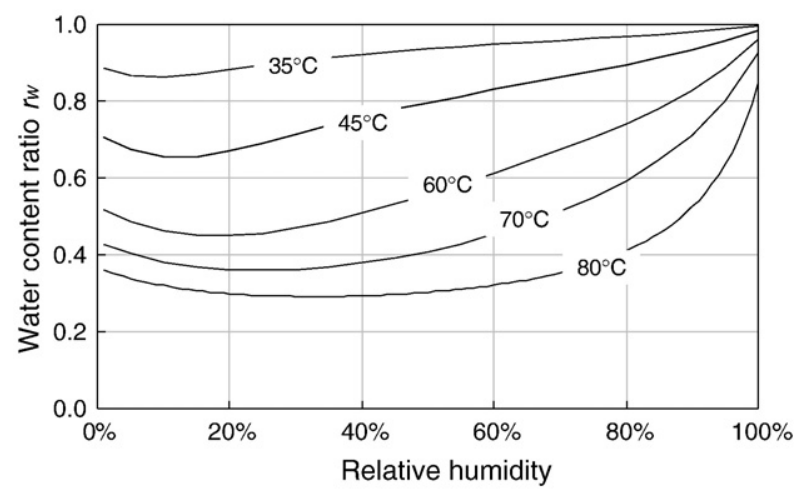

Fig. 10. Evolution of the ratio $r_{\mathrm{w}}(R H, T)$ as a function of temperature and relative humidity.

\section{Conclusion}

In the framework of radioactive waste management and especially in the case of interim storage, concrete structures should be submitted to temperatures up to $80{ }^{\circ} \mathrm{C}$ and subsequent drying. The durability assessment of such structures in such unusual conditions thus requires the knowledge of the first desorption isotherm at $80^{\circ} \mathrm{C}$. An experimental campaign was thus undertaken to characterize the first desorption isotherms (at $30{ }^{\circ} \mathrm{C}$ and $80{ }^{\circ} \mathrm{C}$ ) of a French reference concrete for radioactive waste management. This was done using the desiccator method with massive samples. The results showed an important impact of temperature on the first desorption isotherm:

1. the general shape of the isotherm is modified and leads to more pronounced non-linearities;

2. the water content at equilibrium is drastically reduced at $80^{\circ} \mathrm{C}$ over the whole $\mathrm{RH}$ range;

3. the water content at saturation at $80^{\circ} \mathrm{C}$ is significantly lower than at $30^{\circ} \mathrm{C}$.

The examination of the results led the author to think that the coarsening of the pore structure and the evolution of water properties could not explain these important modifications and that another phenomenon was at work. The latter consists in desorption induced by temperature and can be described using the Clausius-Clapeyron formula. Using the two isotherms acquired, it was possible to evaluate the isosteric heat of desorption and to compare it to the data obtained by Powers and Brownyard using a different method at constant temperature. The two of them are in good agreement. This seems to indicate that the temperature induced desorption is the predominant phenomenon in our experiments (for temperatures less than $80^{\circ} \mathrm{C}$ ).

\section{Acknowledgements}

This work was part of a project funded by Electricité de France (EdF) and the French agency for radioactive waste management (Andra). The author would like to thank Xavier Bourbon (Andra/DS) and Yann LePape (EdF/DER) for their scientific support and also Guillaume Ranc who has initiated this study, Philippe Pétrini for his help in preparing and performing the experiments. Profitable discussions with Sébastien Charles and Christophe Gallé are gratefully acknowledged.

\section{References}

[1] H. Lagrave, Dossier de définition pour l'entreposage de longue durée des déchets HAVL et des combustibles usés (in French), CEA Internal Report DTEC/2005/10, 2005, 55 pp.

[2] H. Lagrave, Dossier de définition de l'entreposage de longue durée des déchets MAVL ou de catégorie B (in French), CEA Internal Report DTEC/2005/11, 2005, 63 p.

[3] J.-F. Daïan, Processus de condensation et de transfert d'eau dans un matériau méso et macroporeux - Etude expérimentale du mortier de ciment (in French), Ph-D Thesis, Institut National Polytechnique de Grenoble (INPG), 1986, 319p.p.

[4] J.-F. Daïan, Condensation and isothermal water transfer in cement mortar, part I pore size distribution, equilibrium, water condensation and imbibition, Transport in Porous Media 3 (6) (1988) 563-589.

[5] F. Radjy, E.J. Sellevold, K.K. Hansen, Isosteric vapor pressure-temperature data for water sorption in hardened cement paste: enthalpy, entropy and sorption isotherms at different temperatures, Report BYG-DTU R057, Technical University of Denmark (DTU), Lyngby, Denmark, 2003, 58 pp.

[6] T. Ishida, K. Maekawa, T. Kishi, Enhanced modeling of moisture equilibrium and transport in cementitious materials under arbitrary temperature and relative humidity history, Cement and Concrete Research 37 (4) (2007) 565-578.

[7] J. Hundt, H. Kantelberg, Sorptionsuntersuchungen an zemestein, zementmörtel und beton (in German), Deutscher Ausschuss für Stahlbeton Heft 297 (1978) 25-39.

[8] Z.P. Bažant, W. Thonguthai, Pore pressure and drying of concrete at high temperature, Journal of the Engineering Mechanics Division (ASCE) 104 (5) (1978) 1059-1079.

[9] Z.P. Bažant, J.C. Chern, W. Thonguthai, Finite element program for moisture and heat transfer in heated concrete, Nuclear Engineering \& Design 68 (1) (1980) 61-70.

[10] Z.P. Bažant, W. Thonguthai, Pore pressure in heated concrete walls - theoretical prediction, Magazine of Concrete Research 31 (107) (1979) 67-76.

[11] B. Bary, A polydispersed particle system representation of the porosity for nonsaturated cementitious materials, Cement and Concrete Research 36 (11) (2006) 2061-2073. 
[12] L.J. Klinkenberg, The permeability of porous media to liquid and gases, American Petroleum Institute, Drilling and Production Practice (1941) 200-214.

[13] CEN, Hygrothermal performance of building materials and products - determination of hygroscopic sorption properties, European Standard EN ISO 12571, European Committee for Standardization (CEN), 2000, 17 pp.

[14] OIML, The scale of relative humidity of air certified against saturated salt solutions, Recommendation R 121, International Organization of Legal Metrology (OIML), 1996, $12 \mathrm{pp}$.

[15] V. Baroghel-Bouny, Water vapour sorption experiments on hardened cementitious materials: Part I. Essential tool for analysis of hygral behaviour and its relation to pore structure, Cement and Concrete Research 37 (3) (2007) 414-437.

[16] Aimin Xu, Water desorption isotherms of cement mortar with fly ash, Nordic Concrete Research 8 (1989) 9-23.

[17] R.M. Espinosa, L. Franke, Influence of the age and drying process on pore structure and sorption isotherms of hardened cement paste, Cement and Concrete Research 36 (10) (2006) 1969-1984.

[18] V. Baroghel-Bouny, B. Perrin, L. Chemloul, Détermination expérimentale des propriétés hydriques des pâtes de ciment durcies - Mise en évidence des phénomènes d'hystérésis (in French), Materials and Structures 30 (6) (1997) 304-348.

[19] F. Radjy, C.W. Richards, Effect of curing and heat treatment history on the dynamic mechanical response and the pore structure of hardened cement paste, Cement and Concrete Research 3 (1) (1973) 7-21.

[20] V. Baroghel-Bouny, M. Mainguy, T. Lassabatere, O. Coussy, Characterization and identification of equilibrium and transfer moisture properties for ordinary and high-performance cementitious materials, Cement and Concrete Research 29 (8) (1999) 1225-1238.

[21] S. Tada, K. Watanabe, Dynamic determination of sorption isotherm of cement based materials, Cement and Concrete Research 35 (12) (2005) 2271-2277.

[22] R.S. Mikhail, G.A. Oweimreen, Surface area and pore structure of compressed lowporosity cement pastes, Cement and Concrete Research 3 (5) (1973) 561-573.

[23] CEN, Testing hardened concrete, part I: shape, dimensions and other requirements for test specimens and moulds, European Standard EN 12390-1, European Committee for Standardization (CEN), 2001, 10 pp.

[24] J.J. Beaudouin, B.T. Tamtsia, Effect of drying methods on microstructural changes in hardened cement paste: an A.C. impedance spectroscopy evaluation, Journal of Advanced Concrete Technology 2 (1) (2004) 113-120.

[25] C. Gallé, Effect of drying on cement-based materials pore structure as identified by mercury intrusion porosimetry. A comparative study between oven-, vacuum-, and freeze-drying, Cement and Concrete Research 31 (10) (2001) 1467-1477.

[26] G.G. Litvan, Variability of the nitrogen surface area of hydrated cement paste, Cement and Concrete Research 6 (1) (1976) 139-144.

[27] J.J. Beaudouin, J. Marchand, Pore structure, in: V.S. Ramachandran, J.J. Beaudouin (Eds.), Handbook of Analytic Techniques in Concrete Science and Technology, Noyes Publications, Park Ridge, USA, 2001, pp. 528-628.

[28] M.C. Garci Juenger, H.M. Jennings, The use of nitrogen adsorption to assess the microstructure of cement paste, Cement and Concrete Research 31 (6) (2001) 883-892.

[29] A. Korpa, R. Trettin, The influence of different drying methods on cement paste microstructures as reflected by gas adsorption: comparison between freeze-drying, D-drying, P-drying and oven-drying, Cement and Concrete Research 36 (4) (2006) 634-649.

[30] J. Adolphs, A. Schreiber, Microstructural characterization of ultra-high performance concrete, in: M. Schmidt, E. Fehling, C. Geisenhanslüke (Eds.), Proceedings of the International Symposium on Ultra-high Performance Concrete, Kasse (Germany), Kassel University, 2004, pp. 265-271.

[31] I. Pane, W. Hansen, Surface characterization of blended cements by $\mathrm{H}_{2} \mathrm{O}$ and $\mathrm{N}_{2}$ sorption isotherms, in: J. Weiss, K. Kovler, J. Marchand, S. Mindess (Eds.), Proceedings of the 1st International Symposium on Advances in Concrete through Science and Engineering, Chicago, USA, RILEM PRO048, 2004.

[32] B.P. Hughes, I.R.G. Lowe, J. Walker, The diffusion of water in concrete at temperatures between 50 and $95^{\circ} \mathrm{C}$. British Journal of Applied Physics 17 (12) (1966) 1545-1552.

[33] N.L. Hancox, The role of moisture diffusion in the drying of cement paste under the influence of temperature gradients, Journal of Physics. D, Applied Physics 1 (12) (1968) 1769-1777.

[34] R. Černy, J. Drchalová, P. Rovnaníková, The effects of thermal load and frost cycles on the water transport in two high-performance concretes, Cement and Concrete Research 31 (8) (2001) 1129-1140.

[35] S.F. Wong, T.H. Wee, S. Swaddiwudhipong, S.L. Lee, Study of water movement in concrete, Magazine of Concrete Research 53 (3) (2001) 205-220.

[36] T.C. Powers, H.M. Mann, L.E. Copeland, The flow of water in hardened Portland cement paste, Portland Cement Association Bulletin 106 (1959) 18p.

[37] R.B. Anderson, Modifications of the Brunauer, Emmett and Teller equation, Journa of the American Chemical Society 68 (4) (1946) 686-691.

[38] C. van der Berg, Vapour Sorption Equilibria and Other Water-Starch Interactions: A Physico-chemical Approach, Ph-D Thesis, Agricultural University of Wageningen, The Netherlands, 1981, 186p.

[39] S. Brunauer, J. Skalny, E.E. Bodor, Adsorption on non porous solids, Journal of Colloid and Interface Science 30 (4) (1969) 546-552.

[40] P.-N.T. Johnson, J.G. Brennan, Moisture sorption isotherm characteristics of plantain (Musa, AAB), Journal of Food Engineering 44 (2) (2000) 79-84.

[41] C.P. McLaughlin, T.R.A. Magee, The determination of sorption isotherm and the isosteric heats of sorption for potatoes, Journal of Food Engineering 35 (3) (1998) 267-280.
[42] A. Jonquières, A. Fane, Modified BET models for modeling water vapor sorption in hydrophilic glassy polymers and systems deviating strongly from ideality, Journal of Applied Polymer Science 67 (8) (1998) 1415-1430.

[43] L.-T. Lim, I.J. Britt, M.A. Tung, Sorption and transport properties of water in Nylon 6, 6 Film, Journal of Applied Polymer Science 71 (2) (1999) 197-206.

[44] Y. Xi, Z.P. Bažant, H.M. Jennings, Moisture diffusion in cementitious materials adsorption isotherms, Advanced Cement Based Materials 1 (6) (1994) 248-257.

[45] S. Bonnet, B. Perrin, Influence de la présence des ions chlorures sur les propriétés à l'équilibre de différents mortiers (chloride influence on equilibrium properties of mortars), Materials and Structures 32 (7) (1999) 492-499.

[46] A. Xu, Water desorption isotherms of cement mortar with fly ash, Nordic Concrete Research 8 (1989) 9-23.

[47] S. Brunauer, P.H. Emmett, E. Teller, Adsorption of gases in multimolecular layers, Journal of the American Chemical Society 60 (2) (1938) 309-319.

[48] IUPAC, Commission on colloid and surface chemistry: reporting physisorption data for gas/solid systems with special reference to the determination of surface area and porosity (Recommendations 1984), Pure and Applied Chemistry 57 (4) (1985) 603-619.

[49] J.B. Condon, Surface area and porosity determinations by physisorption measurements \& theory, Elsevier, $2006274 \mathrm{pp}$.

[50] S.J. Gregg, K.S.W. Sing, Adsorption, surface area and porosity, Academic Press, London, United Kingdom, 1982303 pp.

[51] V. Baroghel-Bouny, Caractérisation des pâtes de ciment et des bétons: Méthodes, analyse, interprétations (in French), Presses du Laboratoire Central des Ponts et Chaussées, Paris, France, 1994468 pp.

[52] I. Odler, The BET-specific surface area of hydrated Portland cement and related materials, Cement and Concrete Research 33 (12) (2003) 2049-2056.

[53] J.J. Thomas, H.M. Jennings, A.J. Allen, The surface area of hardened cement paste as measured by various techniques, Concrete Science and Engineering 1 (1) (1999) 45-64.

[54] I. Odler, J. Hagymassy, M. Yudenfreund, K.M. Hanna, S. Brunauer, Pore structure analysis by water vapor adsorption. IV. Analysis of hydrated Portland cement pastes of low porosity, Journal of Colloid and Interface Science 38 (1) (1972) 265-276.

[55] J. Skalny, I. Odler, Pore structure of calcium silicate hydrates, Cement and Concrete Research 2 (4) (1972) 387-400.

[56] J. Hagymassy, I. Odler, M. Yudenfreund, J. Skalny, S. Brunauer, Pore structure analysis by water vapor adsorption. III. Analysis of hydrated calcium silicates and Portland cements, Journal of Colloid and Interface Science 38 (1) (1972) 20-34.

[57] R.S. Mikhail, S.A. Abo-El-Enein, Studies on water and nitrogen adsorption on hardened cement pastes I - development of surface in low porosity pastes, Cement and Concrete Research 2 (4) (1972) 401-414.

[58] W.H. Bray, E.J. Sellevold, Water sorption properties of hardened cement paste cured or stored at elevated temperatures, Cement and Concrete Research 3 (6) (1973) 723-728

[59] E.J. Sellevold, Mercury porosimetry of hardened cement paste cured or stored at $97^{\circ} \mathrm{C}$, Cement and Concrete Research 4 (3) (1974) 399-404.

[60] T.C. Powers, T.L. Brownyard, Studies of the physical properties of the hardened cement paste, Portland Cement Association Bulletin 22 (1948) 356 pp.

[61] P.C. Carman, F.A. Raal, Role of capillary condensation in physical adsorption, Nature 167 (1951) 112-113.

[62] P.C. Carman, F.A. Raal, Physical adsorption of gases on porous solids I - Comparison between loose powders and porous plugs, Proceedings of the Royal Society of London - Series A, Mathematical and Physical Sciences 209 (1096) (1951) 59-69.

[63] P.C. Carman, Physical adsorption of gases on porous solids II - Calculation of pore-size distribution, Proceedings of the Royal Society of London - Series A Mathematical and Physical Sciences 209 (1096) (1951) 69-81.

[64] R.G. Avery, J.D.F. Ramsay, The sorption of nitrogen in porous compacts of silica and zirconia powders, Journal of Colloids and Interface Science 42 (3) (1973) 597-606.

[65] S.J. Gregg, J.F. Langford, Study of the effect of compaction on the surface area and porosity of six powders by measurements of nitrogen sorption isotherms, Journal of the Chemical Society. Faraday Transactions 73 (1977) 747-759.

[66] S. Brunauer, The adsorption of gases and vapors - Volume I - Physical adsorption, Princeton University Press, 1945511 pp.

[67] D. Myers, Surfaces, interfaces and colloids - Principles and applications, John Wiley, New York, USA, 1999519 pp.

[68] J. Keller, R. Staudt, Gas adsorption equilibria - Experimental methods and adsorption isotherms, Springer Science, Boston, Massachusetts, USA, 2005422 pp.

[69] A.A. Fomkin, Adsorption of gases, vapors and liquids by microporous adsorbents, Adsorption 11 (3) (2005) 425-436.

[70] I.I. Salame, T.J. Bandosz, Experimental study of water adsorption on activated carbons, Langmuir 15 (2) (1999) 587-593.

[71] I.I. Salame, T.J. Bandosz, Adsorption of water and methanol on micro- and mesoporous wood-based activated carbons, Langmuir 16 (12) (2000) 5435-5440.

[72] D.D. Do, Adsorption Analysis: Equilibria and Kinetics, Series on Chemical Engineering Vol. 2, Imperial College Press, London, United Kingdom, 1998913 pp.

[73] R.T. Yang, Adsorbents: fundamentals and applications, John Wiley and Sons, Hoboken, New Jersey, USA, 2003425 pp.

[74] M. Suzuki, Adsorption Engineering, Elsevier Science, Amsterdam, The Netherlands, 1990270 pp. 